Managing higher education institution internationalization: Contemporary efforts of a university in Taiwan

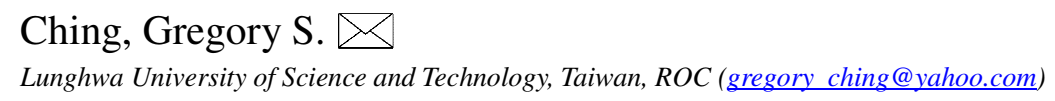

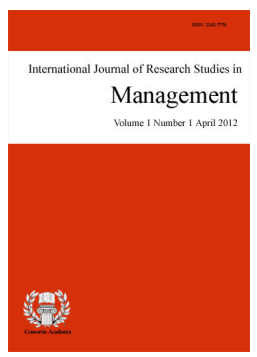

ISSN: 2243-7770 Online ISSN: 2243-7789

OPEN ACCESS

\title{
Abstract
}

As the trend for internationalization of higher education institutions (HEI) becomes more inevitable. Wherein education is not only limited to a country's local clientele. HEIs in Taiwan have employed various strategies in order attract more international faculties and students. However, studies regarding such processes are still limited. In the past few years, National Chengchi University (NCCU); a comprehensive public university in Taiwan, having the mission of improving its international dimension, has decided to set sail on the journey to internationalization with various strategies and activities. This study aims to assess these efforts and their implementation from the viewpoint of the international faculties and international students in NCCU using Chin and Ching (2009) twelve (12) internationalization indicators. A total of 158 international students and 23 international faculties participated in the online survey. Results show that NCCU places strong efforts on producing globally competent graduates and in internationalizing the curriculum, research, and services. However, there is still a need to include more of the internationalization efforts into the university assessments process, which in turn would encouragement further development and improvement in terms of campus internationalization. Additional findings and implications are also given to further aid institutional managers and future researchers regarding the field of contemporary internationalization efforts of East-Asian HEIs.

Keywords: globalization and international higher education; internationalization of higher education; Taiwan; internationalization indicators; performance assessments 


\section{Managing higher education institution internationalization: Contemporary efforts of a university in Taiwan}

\section{Introduction}

Within the last decade, Taiwan's higher education system has experienced transformation along the lines of decentralization and marketization (Mok, 2000). With the revision of the University Act in 1994, which prompted the restructuring of state owned higher education institutions (HEIs) into independent legal entities (Mok, 2006), thereby reducing the control of the Ministry of Education (MOE) over HEIs and making campus operations more flexible. In the following years, Taiwan's government, acknowledging that the state alone can never satisfy the pressing demand for higher education, decided to revise its education ordinances and create room for the expansion of private higher education (Mok, 2000; Mok \& James, 2005). This sparked a growth in the number of HEIs over the decades. Currently, the number of HEIs has increased dramatically from 7 in 1950 to 164 in 2008, among which are 100 universities, 49 colleges, and 15 junior colleges (MOE, 2008). This sudden increased in numbers of HEIs did not only inflame the competition among HEIs, but also hasten the internationalization of Taiwan's HEIs.

National Chengchi University (NCCU); a comprehensive public university in Taiwan, having the mission of improving its international dimension, has decided to set sail on the journey to internationalization in full throttle. Currently, NCCU has close global contact with more than 150 universities and research institutions around the world by means of student and faculty exchange, collaborative research projects, and information sharing. However, studies regarding the effectiveness of such processes are quite limited. In responds this study aims to assess NCCU's internationalization efforts and their implementation, from the viewpoint of the international faculties and international students in NCCU. In addition, this study will utilized the twelve (12) internationalization indicators proposed by Chin and Ching (2009) namely: institutional commitments, strategic planning, funding, institutional policy and guidelines, organizational infrastructure and resources, academic offerings and curriculum, performance evaluation and accountability, internet presence, faculty and faculty development, international students and scholars, study abroad, and campus life, as a mean of evaluating the institutions internationalization efforts.

The following sections shall review the guiding ideas of globalization and internationalization, the twelve internationalization indicators, and previous Taiwanese internationalization related studies. A description of the research process is provided in a subsequent section which leads into an outline of the methodological framework. Next, a summary of the statistical analyses is provided along with a discussion of the results. A concluding discussion offering insights and implications regarding the different internationalization strategies employed shall also be given.

\subsection{Global push for internationalization of higher education}

The examination of globalization and internationalization as distinct processes is essential for serious scholarship addressing contemporary trends in higher education. Scholars agree that processes of globalization are unalterable while those representing internationalization remain fluid and changeable. Elkin, Devjee and Farnsworth (2008) note that, internationalization is not something that is either achieved or not achieved; rather it is an engagement with a range of dimensions (indicators). Internationalization represents university policy, initiatives, and practices that are adopted in response to the affects of globalization (Scott, 1998).

Internationalization at the national, sector, and institutional levels is defined as the process of integrating an international, intercultural, or global dimension, into the purpose, functions or delivery of higher education (Knight, 2004). Ellingboe (1998) added that internationalization is the ongoing process of integrating an 
international perspective into HEIs. It should encompass a multi-dimensional, inter-disciplinary, and future-oriented leadership vision, which involves the many stakeholders of the institution, in order to respond and adapt appropriately to the ever increasingly diverse and global environment. Hence, the many definitions and dimensions of internationalization have definitely given grounds to its complexity.

On the other hand, globalization is considered a multi-dimensional term (Levin, 1999). Commonly, globalization is defined as the closer integration of the countries and peoples of the world, brought about by the enormous reduction of costs of transportation and communication, and the breaking down of artificial barriers to the flows of goods, services, capital, knowledge, and people across borders (Stiglitz, 2002). It also refers to the process and consequences of instantaneous communication and technological advancement, which brought about the tremendous growth in the quantity of information and integration (Grunzweig \& Rinehart, 2002). While academic systems and institutions may make different accommodations to these trends, however neither one can ignore its impetus and implications. Globalization, as it applies to higher education, involves information technology and the use of a common language for scientific communication (Altbach, 2005). In effect, the rapidly changing world thus requires students to possess broad international knowledge and strong intercultural skills, in addition to the more traditional disciplinary knowledge gained from university education (Paige, 2005).

\subsection{Internationalization indicators}

Chin and Ching (2009) proposed twelve indicators that could be used to measure Taiwan's HEIs. These indicators are the synthesized findings from the 37 reviewed internationalization related studies, combined with the results from the individual interviews with foreign internationalization experts, local campus internationalization officers, and international students in Taiwan. Table 1 shows a summary of the twelve indicators.

To explain further, figure 1 shows that the indicators institutional commitments, strategic planning, and funding are placed alongside the inner core triangle, indicating their immediate importance in pursuing a campus wide internationalization. This also denotes that the three indicators are deemed as the foremost issues (also called as the initiators by the authors) to consider before embarking into the internationalization process. These are then followed by the indicators institutional policy and guidelines, organizational infrastructure and resources, faculty and staff development, and performance evaluation and accountability, which are placed alongside the middle square, indicating the next level of indicators. These indicators actually act as linkages between the core (initiators) and the frontline indicators. In other words, these linkage indicators help facilitate the frontline indicators and at the same time assist in carrying out the missions of the core indicators. Finally, the remaining frontline indicators (study abroad, international students and scholars, academic offerings and curriculum, internet presence, and campus life), these are placed alongside the outermost pentagon, denoting the most obvious (observable) characteristics of an internationalizing higher education institution. As the figure shows the over lapping three geometric figures (triangle, square, and pentagon) also denotes that the indicators are inter-related. Although many of the related studies mentioned different indicators, however, these are in fact overlapped and quite similar, but were only categorized somewhat differently. It is observed that authors tend to add context to the indicators, while similarities and commonalities across regions and organizations were observed.

Other studies done regarding Taiwan's HEIs internationalization were also noted. Huang and Chang (2004) explored the internationalization indicators of domestic college students extensively, and chose $\mathrm{Shu} \mathrm{Te}$ University as their case study subject. The authors categorized internationalization into four types, namely: International Organization, International Business, International Experience, and International Media. Results show that students of Shu Te University do indeed recognized the four types of internationalization indicators. In addition, the study also mentioned the importance of internationalized curriculum and foreign language studies. Similarly, Wang (2006) mentioned internationalization in Taiwan is driven by the increased of international trade, the wider availability of capital, improvements in communication, the internationalization of education, and the 
Ching, G. S. \& Chin, M. C.

transfer of technological and managerial skills. Indicators such as internationalized curriculum and the presence of international students and scholars are internationalization trends which are commonly found in Taiwan's HEIs.

\section{Table 1}

Taiwan's HEIs internationalization indicators

\begin{tabular}{ll}
\hline Internationalization indicators & Summarized contents \\
\hline Institutional Commitments & Articulated commitments on internationalization efforts; inclusion \\
& in the mission/vision, goals and objectives; promotion; \\
& membership in local/international academic organizations
\end{tabular}

Strategic Planning

Long term and short term plans for institution, department, faculty, and student levels; internationalization timeline; plan to establish branches; partners with private, public, local, international, academic, and industry

Funding

Seeks funding from various organizations, government, and other private entities

Institutional Policy and Guidelines Faculty policies and guidelines regarding hiring, rewards, sanctions, code of conducts; student policies and guidelines regarding admission, rewards, sanctions, opportunities

Organizational Infrastructure and Availability of an internationalization supporting system Resources including office, professionals and staff, resources

Academic Offerings and Curriculum Foreign language requirements; availability of professional language courses; internationalized curriculum development

Internet Presence

Links to international liaison office or foreign student admission; bilingual information regarding important dates, fees, and news; clear information on requirements together with programs and course offerings; need to know links

Faculty and Staff Development

Provision of support for collaboration, research, conferences, and other internationalization efforts

International Students and Scholars Scholarships, housing, offices, facilities and other support systems; student and language partner/buddy program

Study Abroad

Academic/non-academic travels; travel subsidies; orientation; symposia for incoming and outgoing students

Campus Life

Presence of campus life office and officer; organizations with internationalized theme; formal/informal academic /extra-curricular international activities

Performance Evaluation and Performance and monitoring system indicators; internal/external Accountability reviews; reporting, recommendations, research and studies in internationalization efforts

Source. (Chin \& Ching, 2009, p. 196 \& 198)

L. Y. Chen (2007) used the competing values framework in studying HEIs internationalization in Taiwan. Results show that a quality assurance and accountability measures are needed to ensure a balance between the HEIs in Taiwan. Indicators mentioned in this study are the presence of international students and scholars, institutional policies and guidelines, internationalized curriculum, and performance evaluation and accountability. Hsu (2007) mentioned that HEIs in Taiwan are under the pressure of global competitiveness. In addition, 
internationalization in Taiwan is mostly patterned and modeled with features that have been set according to the advantages of Western developed countries. With English being the predominant language, other indicators such as scientific research output, qualitative and quantitative academic indicators, or even the numbers of Nobel laureates produced, are all favorable to the Western countries.

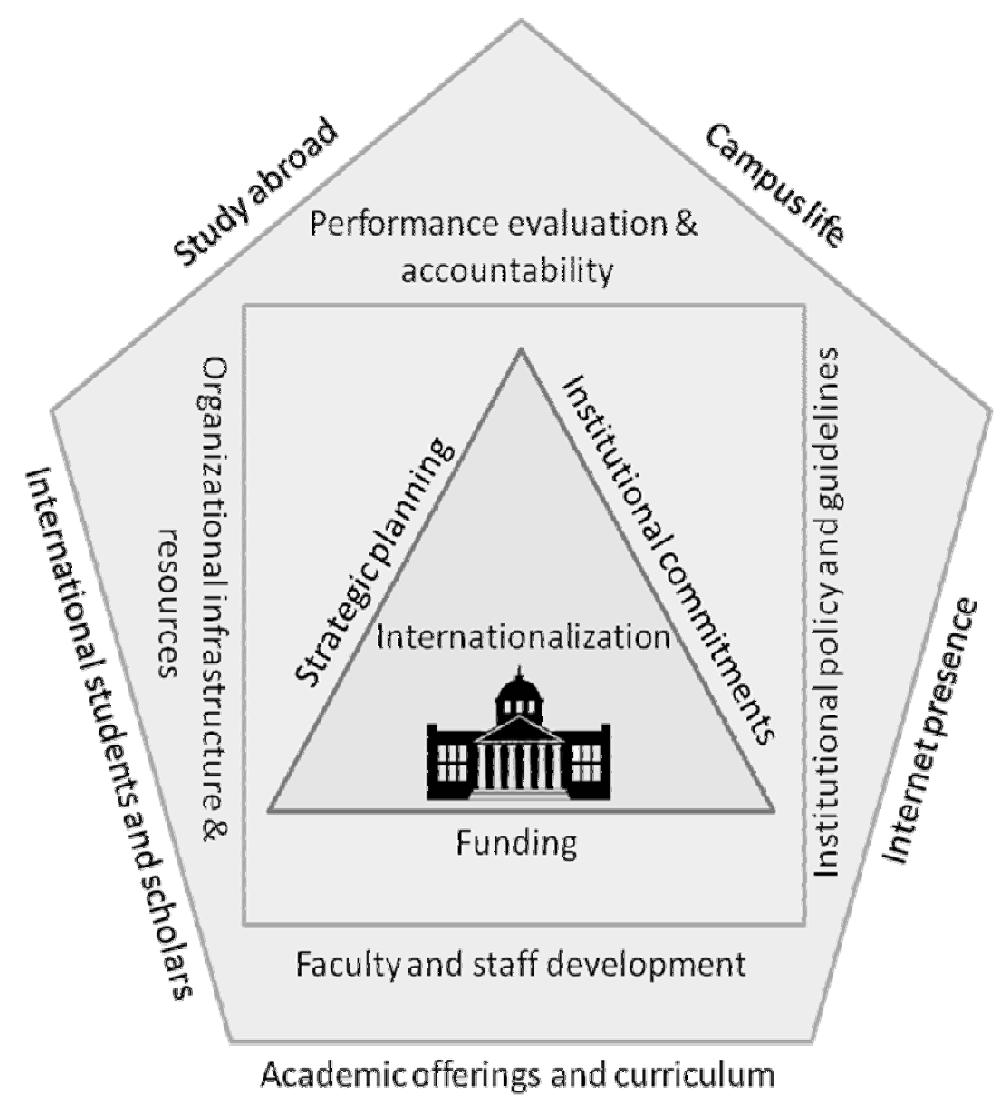

Figure 1. Taiwan higher education internationalization paradigm

Lu (2007) mentioned that the major strengths generated by the internationalization of Taiwan's HEIs depend on the strong support and drive from the related administration. The major weakness of Taiwan's HEIs is in the failure to attract international students, not being able to adapt to global trends, and insufficient faculty incentives. While, Chiang (2008) did a comparative analysis between internationalization strategies and actual implementation of such strategies. Results show that strategic planning is definitely an important indicator of internationalization. However, the current implementation status of such internationalization strategies is still in its early stages. More active promotion and motivation should be implemented to further aid in the internationalization efforts of Taiwan's HEIs.

Lastly, C. L. Chen (2009) did a study on 5 public and private universities in Taiwan. The study mentioned six internationalization indicators, namely: teachers, students, research internationalization, course program internationalization, international visibility, and internationalization of administration and campus. Additional results showed that the evaluation mechanism on Taiwan's HEIs internationalization is still not enough. Furthermore, the current existing indicators lack the international vision of students and international courses and therefore their accuracy and appropriateness are quite disputable (C. L. Chen, 2009). For internationalization strategy, the results show that the investment of educational resources by the government is insufficient in comparison with the nearby countries.

In summary, numerous research results have suggested that the Taiwanese government should invest more resources; long term financial assistance, as against to short term support. This would then foster a long term 
academic interactions between teaching and research, while developing a quality education system. However, in order to gain deeper insights into the management of the internationalization efforts of HEIs, this study shall try to answer the following research questions:

1. How effective are the internationalization efforts of NCCU as perceived by the international faculties and students?

2. Is there a difference between the international faculties and international students' level of perception?

3. What are the effective strategies employed by NCCU to further enhanced their campus internationalization?

\section{Methodology}

Researchers who conduct research involving international dimensions note the importance of primary sources as a viable option for data collection (Pinar, Reynolds, Slattery, \& Taubman, 1996). The investigation therefore was initiated with a review of sources to develop a contemporary reference for the issues and trends in the measurement of higher education internationalization around the globe. The inspection of written documents such as books, periodicals, newspapers, and legal documents to gain a foundation for the history, geography, ecological needs, and community efforts at work in Taiwan were ongoing during all stages of investigation.

This study employs the descriptive research paradigm; a research that is concerned with how what is or what exists is related to some preceding event that has influenced or affected a present condition or event. Descriptive research, according to Best (1970) is concerned with conditions or relationships that exists; practices that prevail; beliefs, points of views, or attributes that are held; processes that are going on; effects that are being felt; or trends that developing. For data gathering, a survey questionnaire based on Chin and Ching (2009) twelve internationalization indicators was used. In addition, Green's $(2005 ; 2008 ; 2003)$ internationalization index was also considered in formulating the specific surveyed items. Lastly, most survey will combine nominal data on participants' backgrounds and relevant personal details with other scales (Weisberg, Kronsnick, \& Bowen, 1996).

The survey questionnaire was administered using the internet as a platform for collecting data. Although internet-based or online surveys have many features in common with paper-based surveys, it also has its own particular features (Cohen, Manion, \& Morrison, 2007). Watt (1997) mentioned that some of the advantages of using an online survey are the reduced costs in encoding and processing data. In addition, it also reduces the time needed to distribute, gather, and process data. Online survey enables a wider and much larger population to be accessed, allowing researchers to reach difficult populations under the cover of anonymity and non-traceability (Dillman \& Bowker, 2000).

The online survey was separated into two groups: one for the degree seeking and exchange program international students, and one for the international faculties in NCCU. Since the international faculties and international students are exposed to different levels of internationalization, the indicators included for the students survey is limited to only eight (8), as for the complete twelve (12) indicators for the faculties. An email was sent to all international students and faculties, announcing the online survey. As of school year 2008, NCCU has a total of 464 international students including exchange program students and degree seeking students. A total of 158 international students participated in the online survey, which indicates $34 \%$ participation. For the international faculty, 23 out of 65 participated in the online survey, which indicates $35 \%$ participation.

Results gathered from the survey questionnaire was then encoded and analyzed using the Statistical Package for the Social Sciences (SPSS) version 15. Descriptive statistics was accomplished, wherein the mean, standard deviation (SD) and percentage of the respondents' selection are tabulated, analyzed, and conclusion drawn. Correlation comparison among the different items was also included to further give insights in the internationalization efforts of the institution. 


\section{Results and discussions}

The first part of the survey includes the profile of the participants. Table 2 shows the profile of the international students participants. The student participants have a mean age of 27.65 years old, with the number of male and female participants 82 and 76 respectively. The profile also indicates that $79 \%$ (124) of the participants have already stayed at NCCU for more than a year. In addition, the participants used an average of three languages and about 60\% (94) are in the Masters program. This is quite remarkable, which indicate that besides their first language and Chinese Mandarin language (assuming that they studied Mandarin Chinese in Taiwan), most of the participants are knowledgeable with another language. In addition, most of the participants are graduate students, which would indicate the evidence of NCCU's commitment to internationalization is also apparent in its curriculum of newly established degree programs including: the IMBA (International MBA), IMTS (International Master's Program in Taiwan Studies), IMCS (International Master Program in China Studies), IMICS (The International Master Program in International Communication Studies) and the ETP (English Taught Program).

Table 2

International student online survey participants' profile $(N=158)$

\begin{tabular}{|c|c|c|c|c|c|c|}
\hline Items & $n$ & $\%$ & $M$ & $S D$ & Min. & Max. \\
\hline $\mathrm{Age}^{\mathrm{a}}$ & & & 27.65 & 5.16 & 19 & 46 \\
\hline Male & 82 & 52 & 28.62 & 5.39 & 21 & 46 \\
\hline Female & 76 & 48 & 26.61 & 4.71 & 19 & 39 \\
\hline Duration in $\mathrm{NCCU}^{\mathrm{b}}$ & & & 2.34 & 1.03 & 1 & 5 \\
\hline 1 year or less & 34 & 21 & & & & \\
\hline 2 years or less & 62 & 39 & & & & \\
\hline 3 years or less & 42 & 27 & & & & \\
\hline More than 3 years & 20 & 13 & & & & \\
\hline Languages used $^{\mathrm{c}}$ & & & 3.20 & 1.03 & 1 & 6 \\
\hline 2 or less & 36 & 23 & & & & \\
\hline 3 & 69 & 44 & & & & \\
\hline 4 & 37 & 23 & & & & \\
\hline 5 or more & 16 & 10 & & & & \\
\hline \multicolumn{7}{|l|}{ Program level } \\
\hline Undergraduate / College & 56 & 35 & & & & \\
\hline Masters & 94 & 60 & & & & \\
\hline Ph. D. & 8 & 5 & & & & \\
\hline
\end{tabular}

Note. ${ }^{\mathrm{a}} \mathrm{Age}$ is in years, ${ }^{\mathrm{b}}$ Duration is in years, ${ }^{\mathrm{C}}$ Includes spoken and written language

Table 3 shows the breakdown of student participants with respect to their country of origin, together with the actual number of student coming from the respective countries. About $16 \%$ (25) of the student participants came from the United States, while around 12\% (19) comes from Malaysia. Majority of NCCU international student population comes from countries such as Korea, Japan, and the United States. Since the survey is done in English, Korean and Japanese students tends to shy away from it. However, the survey still attracted 15 out of 69 Koreans students, and 14 out of 54 Japanese students in NCCU, which is about $22 \%$ and $26 \%$ respectively of their total population. 
Ching, G. S. \& Chin, M. C.

Table 3

International student online survey participants' country of origin $(N=158)$

\begin{tabular}{|c|c|c|c|c|}
\hline Country & $n$ & $\%$ & $n^{\mathrm{a}}$ & $\%^{\mathrm{a}}$ \\
\hline Argentina & 1 & 0.6 & 3 & 33 \\
\hline Australia & 1 & 0.6 & 6 & 17 \\
\hline Canada & 6 & 3.8 & 24 & 25 \\
\hline Costa Rica & 1 & 0.6 & 4 & 25 \\
\hline Czech & 1 & 0.6 & 7 & 14 \\
\hline Gambia & 1 & 0.6 & 2 & 50 \\
\hline Germany & 6 & 3.8 & 12 & 50 \\
\hline Guatemala & 3 & 1.9 & 5 & 60 \\
\hline Haiti & 1 & 0.6 & 3 & 33 \\
\hline Honduras & 4 & 2.5 & 5 & 80 \\
\hline India & 4 & 2.5 & 9 & 44 \\
\hline Indonesia & 9 & 5.7 & 14 & 64 \\
\hline Ireland & 2 & 1.3 & 2 & 100 \\
\hline Italy & 1 & 0.6 & 3 & 33 \\
\hline Japan & 14 & 8.9 & 54 & 26 \\
\hline Korea & 15 & 9.5 & 69 & 22 \\
\hline Lithuania & 2 & 1.3 & 4 & 50 \\
\hline Malawi & 1 & 0.6 & 2 & 50 \\
\hline Malaysia & 19 & 12 & 23 & 83 \\
\hline Mongolia & 1 & 0.6 & 7 & 14 \\
\hline Nicaragua & 4 & 2.5 & 9 & 44 \\
\hline Panama & 2 & 1.3 & 4 & 50 \\
\hline Paraguay & 1 & 0.6 & 1 & 100 \\
\hline Peru & 3 & 1.9 & 4 & 75 \\
\hline Philippines & 2 & 1.3 & 3 & 67 \\
\hline Poland & 3 & 0.6 & 8 & 38 \\
\hline Russia & 4 & 2.5 & 12 & 33 \\
\hline Singapore & 10 & 6.3 & 11 & 91 \\
\hline Slovak & 1 & 0.6 & 2 & 50 \\
\hline Thailand & 2 & 1.3 & 9 & 22 \\
\hline UK & 4 & 2.5 & 5 & 80 \\
\hline USA & 25 & 15.8 & 55 & 45 \\
\hline Vietnam & 4 & 2.5 & 4 & 100 \\
\hline
\end{tabular}

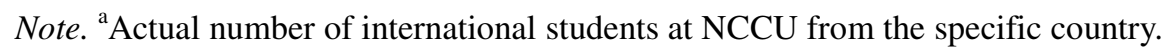

For the international faculty's survey, Table 4 shows the profile of the participants. The mean age is equal to 43 years old, wherein, the number of male participants is $78 \%$ (18) and $22 \%$ (5) for the female participants. Around 56\% (13) of the participants have been with NCCU for more than three years, which indicate that the responding faculties are quite accustomed with NCCU internationalization policies and efforts. In addition, the average language the participants used is three, and around $61 \%$ of the participants came from the Americas and the rest from Europe. 
Managing higher education institution internationalization: Contemporary efforts of a university

Table 4

International faculty online survey participants' profile $(N=23)$

\begin{tabular}{|c|c|c|c|c|c|c|}
\hline Items & $n$ & $\%$ & $M$ & $S D$ & Min. & Max. \\
\hline $\operatorname{Age}^{a}$ & & & 43.00 & 9.58 & 27 & 66 \\
\hline Male & 18 & 78 & 43.50 & 8.63 & 33 & 66 \\
\hline Female & 5 & 22 & 41.20 & 13.54 & 27 & 55 \\
\hline Duration in $\mathrm{NCCU}^{\mathrm{b}}$ & & & 4.70 & 4.69 & 0 & 20 \\
\hline 1 year or less & 4 & 18 & & & & \\
\hline 2 years or less & 6 & 26 & & & & \\
\hline 3 years or less & 3 & 13 & & & & \\
\hline 5 years or less & 3 & 13 & & & & \\
\hline 10 years or less & 4 & 17 & & & & \\
\hline More than 10 years & 3 & 13 & & & & \\
\hline Languages used $^{c}$ & & & 3.52 & 1.08 & 2 & 6 \\
\hline 2 or less & 4 & 17 & & & & \\
\hline 3 & 8 & 35 & & & & \\
\hline 4 & 7 & 31 & & & & \\
\hline 5 or more & 4 & 17 & & & & \\
\hline \multicolumn{7}{|l|}{ Courses taught } \\
\hline Foreign languages & 13 & 57 & & & & \\
\hline Business & 5 & 22 & & & & \\
\hline Science & 4 & 17 & & & & \\
\hline Philosophy & 1 & 4 & & & & \\
\hline \multicolumn{7}{|l|}{ Regions of origin } \\
\hline Europe & 9 & 39 & & & & \\
\hline Americas & 14 & 61 & & & & \\
\hline
\end{tabular}

Note. ${ }^{\mathrm{a}}$ Age is in years, ${ }^{\mathrm{b}}$ Duration is in years, ${ }^{\mathrm{c}}$ Includes spoken and written language

The measure of reliability as internal consistency of the online survey was done by computing for the Lee Cronbach's (1951) coefficient alpha, frequently referred to as the alpha coefficient of reliability or simply the alpha (Cohen et al., 2007). The overall alpha of 0.976 and 0.944 for the student's and faculty's survey is considered quite good (Nunnally \& Bemstein, 1994). A popular rule of thumb is the size should be generally greater than or equal to 0.70 indicate an acceptable level of reliability, and those greater or equal to 0.80 demonstrate very good reliability for research purposes (Johnson \& Christensen, 2008).

The perceived internationalization of NCCU is measured by means of asking the participants the extent of presence of the mentioned items. The scales used are the following: None at all, Very little, A little, A lot, and A very great deal, which are weighted from 1 to 5 respectively. For the results of the internationalization indicator institutional commitments, the highest item for the student's survey is internationalization is stated as one of the top institutional priorities with a mean of 3.77, and for the faculty's survey is an administrative level position for international education is present with a mean of 4.30. These suggest that the schools internationalization effort is clearly felt by the international student population. Similarly, the presence of an administrative level position for international education means that NCCU placed international education as one of its priorities. In addition, the lowest item is the same for both the survey, which is formal evaluation on the impact or progress of internationalization is periodically done with a mean of 3.07 and 2.70 respectively. Although educational evaluation (or assessment; process undergone is quite similar to institutional accreditation of the west) is done periodically, actual inclusion of the internationalization indicators as a part of the evaluation process is very limited. 
For the internationalization indicators strategic planning and funding (indicators only available for the international faculties). The highest items are the plan sets for periodic internal and external performance evaluation for strategic planning and received funding from the government for funding with means of 4.17 and 3.43 respectively. Considering that the item on evaluation of internationalization in the indicator institutional commitments was deem lowest, which clearly coincides with the assumption that although NCCU set plans for both internal and external performance evaluations, the inclusion of evaluation regarding the campus internationalization efforts are still quite limited. For the lowest items are the plan lists specific internationalization activities for the university and the received funding from foreign international sources with means of 2.83 and 2.39 respectively. With regards to the lack of specific plans for university wide internationalization activities, most faculty participants select the scale 'a little', results suggest that NCCU should increase the promotion of internationalization related activities. Primarily, this would help promote the activities and more importantly increase the number of participants, hence, improve interaction among the local and international community in NCCU. In addition, with regards to funding, NCCU is successful in seeking financial support from the government and should exert more effort on the other sources, like the private industries, and foreign organizations, and/or governments.

The results for the internationalization indicator institutional policies and guidelines, the highest item for both the student's and faculty's survey is the foreign language graduation requirement for students with means of 3.44 and 4.09 respectively. This shows that NCCU's effort in having their graduates verse in foreign languages is quite effective. For the lowest item, both the student's and faculty's survey suggested that policies/guidelines which ensures students can participate in approved study abroad programs without delaying graduation with means of 3.15 and 3.57 respectively. Although it's the lowest item, however it still indicate and rank that there is 'a little' going towards to 'a lot' of the item present in NCCU.

For the internationalization indicator organizational infrastructure and resources, the highest item for the student's and faculty's survey is full-time staff to assist in administering international activities \& programs, with means of 3.65 and 4.22 respectively. In addition, the faculty's survey has another item with a mean of 4.22 , which is the item a study abroad office with qualified professionals. For the lowest item in the student's survey is the staff responsible for the achievement of timelines and targets with a mean of 3.17 , and for the faculty's survey the item faculty \& department committees responsible for international education with a mean of 2.83 . This would indicate that although NCCU has an administrative level officer handling the international education, there is still a need to improve it on the departmental levels.

For the internationalization indicator academic offerings and curriculum, both the student's and faculty's survey have ranked the availability of foreign language programs as the highest item, with means of 3.74 and 4.52 respectively. This clearly indicates that NCCU foreign language courses (not limited to Mandarin studies program) as one of its competitive advantages and is clearly seen as a strong factor in its internationalization efforts. For the lowest item in the student's survey is the gives credit to international activities like study abroad, international internships, international service opportunities, and the like with a mean of 2.92 , and for the faculty's survey the item an international education curriculum committee with a mean 2.91 . This clearly coincides with the previous lowest item for the organizational infrastructure and resources, which indicate the need for NCCU to farther improve the items regarding international education in the departmental levels.

For the internationalization indicator faculty and staff development (indicator only available for the international faculties), the highest item for the faculty's survey is funding for inviting foreign faculties either short-term or long-term visits with a mean of 4.30. This clearly indicates that NCCU has been investing financially in the effort of having foreign scholars in the campus. For the lowest item is release time for faculty to work on university sponsored development assistance projects with a mean 2.96. Although is it the lowest item, however, considering the value of 2.96 nearing 3.00, which indicate 'a little' and means that there is the presence but not so much. 
Managing higher education institution internationalization: Contemporary efforts of a university

For the internationalization indicator international students and scholars, the highest item for the student's survey is the scholarships for international students with a mean of 4.00 , and for the faculty's survey is housing for international faculties/scholars with a mean 4.65. This clearly suggests that scholarships and housing for international students and faculties are considered to be top priority. The lowest item for the student's survey is $a$ channel for international scholar like Fulbright, and the like with a mean of 2.94, and for the faculty's survey is recruitment strategy for international students with a mean of 3.17. This indicates that both students and faculties are not exposed to the recruitment process of the other. In any case their means are not that low, which could indicate the need for little improvement.

For the internationalization indicator study abroad, the highest item for both the student's and faculty's survey is the signing of student exchange agreements with partner universities abroad with means of 3.62 and 4.61 respectively. This clearly indicates the success of NCCU's internationalization efforts regarding the signing of memorandum of understanding and/or agreements (MOU/MOA). While the lowest item for student's survey is non-academic programs abroad such as work and tourism programs with a mean of 2.84 , and for the faculty's survey is pre-departure, in-country, and re-entry orientation programs for study abroad students with a mean of 3.26. For the indicator internet presence, both students and faculties ranked all the items quite high, which means that they are all satisfy with the NCCU's website performance. However, for the item hyperlinks to website of interest to international students' (such as weather bureau, immigration office, and the like) easily available with a mean of 3.20, which is the lowest for the indicator.

For the internationalization indicator campus life, the highest item for student's survey is campus information, signage, billboards, and the like are written in bilingual language with a mean of 3.59, and for the faculty's survey is the presence of the campus life office or similar office responsible for the international aspect of students' life with a mean of 4.30. These clearly show the effort of NCCU in enhancing its campus life factors as beneficial to its internationalization. For the lowest item, both student's and faculty's survey suggested that there is a need to improve the factor career development center with international job placements \& advising with means of 2.75 and 2.48 .

Lastly, for the internationalization indicator performance evaluation and accountability (indicator only available for the international faculties), the highest item is a formal performance evaluation procedure is in place with a mean of 3.48. Again, this clearly coincide with the previous answers that NCCU has indeed evaluation procedures in place. For the lowest item is conducts external reviews of internationalization with a mean 2.61. Similar with the previous answers, NCCU needs an evaluation mechanism specifically tailored for the internationalization efforts of the institution.

In sum, table 5 shows the overall perception on NCCU's internationalization. The student's survey having an average mean of 3.38, while the faculty's survey having an average mean of 3.64, with the faculty scoring slightly higher than the students. Finally, the general (grand) overall means of the two surveys; considering that all internationalization indicators and both survey weighted the same, is 3.51. This clearly indicates that NCCU internationalization efforts is in the middle of ' $a$ little' to 'a lot', which would mean a moderately internationalized institution.

\section{Conclusion}

In the last decade, university performance has drawn much attention from the public; hence university ranking and international benchmarking are becoming more central in university governance. Likewise, governments in East Asia have started comprehensive reviews of their higher education systems, which prompted the internationalization of HEIs. Therefore, it is not surprising that internationalization processes and strategies are becoming increasingly popular, while internationalization performance assessments consistently emphasized. 
Ching, G. S. \& Chin, M. C.

\section{Table 5}

Overall perception on internationalization

\begin{tabular}{|c|c|c|c|c|}
\hline Internationalization indicators & $N^{a}$ & Mean $^{\mathrm{a}}$ & $N^{b}$ & Mean $^{\mathrm{b}}$ \\
\hline Institutional Commitments & 158 & 3.47 & 23 & 3.73 \\
\hline Strategic Planning & & & 23 & 3.52 \\
\hline Funding & & & 23 & 3.06 \\
\hline Institutional Policy \& Guidelines & 158 & 3.33 & 23 & 3.75 \\
\hline Organizational Infrastructure \& Resources & 158 & 3.41 & 23 & 3.60 \\
\hline Academic Offerings \& Curriculum & 158 & 3.21 & 23 & 3.74 \\
\hline Internet Presence & 158 & 3.77 & 23 & 3.78 \\
\hline Faculty \& Staff Development & & & 23 & 3.64 \\
\hline International Students \& Scholars & 158 & 3.40 & 23 & 4.07 \\
\hline Study Abroad & 158 & 3.20 & 23 & 3.81 \\
\hline Campus Life & 158 & 3.22 & 23 & 3.79 \\
\hline Performance Evaluation \& Accountability & & & 23 & 3.21 \\
\hline Overall & 158 & 3.38 & 23 & 3.64 \\
\hline Grand overall $^{\mathrm{d}}$ & 181 & 3.51 & & \\
\hline
\end{tabular}

Note. 'International student's online survey' ${ }^{\mathrm{b}}$ International faculty's online survey

${ }^{c}$ Overall is computed by means of taking the sum of all the average means of each internationalization indicators, which is then divided by the total number of indicators

${ }^{\mathrm{d}}$ Grand overall is computed by means of adding the two overall means then dividing by two

The current study attempts to examine previous local attempts and works regarding HEIs internationalization, more specifically, the internationalization efforts of a comprehensive university in Taiwan; NCCU. Chin and Ching (2009) twelve internationalization indicators are used to determine the perceived effectiveness of internationalization efforts by the international faculties and students. The twelve indicators are the following: Institutional commitments, strategic planning, funding, institutional policy and guidelines, organizational infrastructure and resources, academic offerings and curriculum, internet presence, faculty and faculty development, international students and scholars, study abroad, campus life, and performance evaluation and accountability.

Currently, NCCU is working with over 100 elite institutions around the world by means of student and faculty exchange, collaborative research projects, and information sharing. Strong efforts are also place on producing globally competent graduates and in internationalizing the curriculum, research, and services. This study aims to assess these efforts and their implementation, from the viewpoint of the international faculties and students in NCCU. In response, an online survey was administered to measure NCCU's internationalization according to the above mentioned indicators. Some important implications are as such: 
Managing higher education institution internationalization: Contemporary efforts of a university

$>\mathrm{NCCU}$ is moderately internationalized with a grand mean of 3.51 and there exist a slight difference between the international faculties and international students' perceived internationalization (with faculties scored slightly higher than students);

$>$ In addition to the presence of an administrative level position for international education. The presence of the Office of International Cooperation (OIC) are both deemed as highly important and effective by both the international students and faculties;

$>$ Signing of MOA/MOU and the presence of student exchange programs are seen as strong efforts in NCCU's internationalization;

$>$ The availability of scholarships and housing for international students and scholars are definitely a plus factor in NCCU's internationalization efforts;

$>$ The availability of foreign language courses is deemed as one of the competitive advantages of NCCU;

Although there is a performance evaluation mechanism in place, there is still a need to include more of the internationalization efforts into the assessments process, which would encouragement development and improvement.

Many scholars would claim that in the last decade they have witnessed a dramatic movement of internationalization rationales toward income production. While this trend might be true for a small group of countries, it is certainly not the case for the majority of institutions around the world. For NCCU, current motivations are still focus on enhancing the international curriculum programs and encouraging international enrollments. In essence, while NCCU's internationalization efforts are still in the early stages, numerous efforts are already in place, however further improvement are still needed to further improve the overall internationalization of NCCU.

NOTE: Earlier versions of this paper have been presented at the 2008 Annual Conference of the Society for Research into Higher Education in United Kingdom and at the 2009 Annual Conference of the Comparative Education Society of Hong Kong in Macau.

Acknowledgement: This paper is part of a longer Doctoral Dissertation accomplished in 2009 for the Graduate Program of Education at the National ChengChi University in Taiwan.

\section{References:}

Altbach, P. G. (2005). Globalization and the university: Myths and realities in an unequal world. In The NEA 2005 Almanac of Higher Education (pp. 63-74). Washington, DC: National Education Association.

Best, J. W. (1970). Research in education. Englewood Cliffs, NJ: Prentice Hall.

Chen, C. L. (2009). A study of the construction of measurement indicators and the internationalized strategies for higher education in Taiwan [In Chinese]. Unpublished Ph. D. dissertation, National Sun Yat Sen University, Kaohsiung.

Chen, L. Y. (2007). Implications of competing values framework for developing internationalization indicators in higher education evaluation plan [In Chinese]. Journal of Educational Administration and Evaluation, 3, $1-18$.

Chiang, L. C. (2008). Rethinking the state of the art of internationalization of higher education in Taiwan from the nature of strategy and execution [In Chinese]. Educational Resources and Research Bimonthly 8(83), 47-70. 
Ching, G. S. \& Chin, M. C.

Chin, J. M.-C., \& Ching, G. S. (2009). Trends and indicators of Taiwan's higher education internationalization. The Asia-Pacific Education Researcher, 18(2), 185-203. doi:10.3860/taper.v18i2.1322 $<$ http://dx.doi.org/10.3860/taper.v18i2.1322>

Cohen, L., Manion, L., \& Morrison, K. (2007). Research methods in education. New York: Routledge.

Cronbach, L. J. (1951). Coefficient alpha and the internal structure of tests. Psychometrika, 16, 197-334. doi:10.1007/BF02310555 <http://dx.doi.org/10.1007/BF02310555>

Dillman, D. A., \& Bowker, D. K. (2000). The web questionnaire challenge to survey methodologists. In B. Batinic (Ed.), Online social sciences (pp. 53-71). Seattle: Hogrefe \& Huber.

Elkin, G., Farnsworth, J., \& Templer, A. (2008). Strategy and the internationalisation of universities. International Journal of Educational Management, 22(3), 239-250. doi:10.1108/09513540810861874 <http://dx.doi.org/10.1108/09513540810861874>

Ellingboe, B. J. (1998). Divisional strategies to internationalize a campus portrait: Results, resistance, and recommendations from a case study at a US university. In J. A. Mestenhauser \& B. J. Ellingboe (Eds.), Reforming the higher education curriculum: Internationalizing the campus (pp. 198-228). Washington, DC: American Council on Education.

Green, M. F. (2005). Measuring internationalization at research universities. Washington, DC: American Council on Education.

Green, M. F., Luu, D. T., \& Burris, B. (2008). Mapping internationalization on US Campuses: 2008 Edition. Washington, DC: American Council on Education.

Green, M. F., \& Olson, C. (2003). Internationalizing the campus: A user's guide. Washington, DC: American Council on Education.

Grunzweig, W., \& Rinehart, N. (Eds.). (2002). Rocking in red square: Critical approaches to international education in the age of cyberculture. Berlin: Lit Verlag.

Hsu, Y. H. (2007). The feasibility to internationalize Taiwan's higher education system from the perspective of globalization [In Chinese]. Unpublished Ph. D. dissertation, National Sun Yat Sen University, Kaohsiung.

Huang, C. Y., \& Chang, Y. R. (2004). The study of internationalization index of undergraduate students in Taiwan: A case of Shu Te University [In Chinese]. Commerce and Management Quarterly, 5(4), 417-433.

Johnson, B., \& Christensen, L. (2008). Educational research - Quantitative, qualitative, and mixed approaches (3rd ed.). Thousand Oaks, California: Sage Publications.

Knight, J. (2004). Internationalization remodeled: Definition, approaches, and rationales. Journal of Studies in International Education, 8(1), 5-31. doi:10.1177/1028315303260832 $<$ http://dx.doi.org/10.1177/1028315303260832>

Levin, J. S. (1999). Missions and structures: Bringing clarity to perceptions about globalization and higher education in Canada. Higher Education, 37, 377-399. doi:10.1023/A:1003635731222 <http://dx.doi.org/10.1023/A:1003635731222>

Lu, H. L. (2007). The impact of organizational strategy on internationalization of university [In Chinese]. Unpublished Ph. D. dissertation, Soochow University, Shihlin, Taipei.

MOE. (2008). 2008 Educational statistical indicators. Retrieved May 25, 2008, from http://english.moe.gov.tw/lp.asp?ctNode=816\&CtUnit=507\&BaseDSD=7\&mp=1

Mok, K. H. (2000). Reflecting globalization effects on local policy: Higher education reform in Taiwan. Journal of Education Policy, 15(6), 637-660. doi:10.1080/02680930010000236 <http://dx.doi.org/10.1080/02680930010000236>

Mok, K. H. (2006, January 13-14). Questing for internationalization of universities in East Asia: Critical reflections. Paper presented at the International symposium, Osaka University, Japan.

Mok, K. H., \& James, R. (Eds.). (2005). Globalization and higher education in East Asia. Singapore: Marshall Cavendish Academic.

Nunnally, J. C., \& Bemstein, L. H. (1994). Psychometric theory. New York: McGraw-Hill.

Paige, R. M. (2005). Internationalization of Higher Education: Performance Assessment and Indicators. Nagoya Journal of Higher Education, 5, 99-122.

Pinar, W. F., Reynolds, W. M., Slattery, P., \& Taubman, P. M. (1996). Understanding curriculum: An introduction to the study of historical and contemporary curriculum discourses. New York: Peter Lang.

Scott, P. (1998). Massification, internationalization and globalization. In P. Scott (Ed.), The globalization of higher education. Buckingham: SRHE and Open University Press.

Stiglitz, J. E. (2002). Globalization and its discontents. New York: W. W. Norton \& company.

Wang, S. Y. (2006). Internationalization of university in Taiwan and the tendency of the world [In Chinese]. Taipei: NIOERAR. 
Managing higher education institution internationalization: Contemporary efforts of a university

Watt, J. (1997). Using the internet for quantitative survey research. Retrieved November 29, 2008, from http://www.quirks.com/articles/a1997/19970610.aspx?searchID=21889412

Weisberg, H. F., Kronsnick, J. A., \& Bowen, B. D. (1996). An introduction to survey research, polling, and data analysis (3rd edition). Thousand Oaks, CA: Sage. 